\title{
Internal Company Factors as Determining Variables for Improving Bank Lending
}

\author{
Dian PRAWITASARI ${ }^{1}$, Ana KADARNINGSIH ${ }^{2}$, Zaky MACHMUDDAH ${ }^{3}$, Maaz UD-DIN ${ }^{4}$
}

Received: June 03, 2020 Revised: June 28, 2020 Accepted: July 09, 2020

\begin{abstract}
This study seeks to examine the main factors, external and internal to the bank, that enhance bank lending. Bank lending is one of the connecting bridges in sustaining society. Internal factors consist of ROA, DPK, and CAR. External factors are economic growth and interest rate of Bank Indonesia. The population of this research consists of traditional commercial banks listed on the IDX over the 2014-2017 period. Samples were chosen by purposive sampling method. This study uses secondary data with 56 samples; data analysis uses multiple linear regression. The findings of the study show that internal factors have a greater impact on increasing bank lending than external factors. The main variable among internal factors that influences increase in bank lending is ROA. DPK is the internal factor with the smallest impact on increasing bank lending. The implication of the study is that determining the bank lending should take more account of CAR, DPK, ROA, BI interest rates, and economic growth in making decisions about the amount of lending. These variables can only have a slight effect on increasing lending, though. Besides, internal factors such as NPL, LDR or non-economic factors also need to be considered in channeling bank credit.
\end{abstract}

Keywords: Return on Assets, Capital Adequacy Ratio, Third Party Funds, Economic Growth, BI Rate

JEL Classification Code: G21, G24, G29

\section{Introduction}

The financial system in Indonesia is monopolized by banking assets. However, the ratio between GDP and banking assets in 2016 was 0.51 , which is relatively low, thereby reducing bank intermediation activities. However, CAR,

${ }^{1}$ First Author. Lecturer, Management Department, Faculty of Economic and Business, University of Dian Nuswantoro, Indonesia. Email: dian.prawitasari@dsn.dinus.ac.id

${ }^{2}$ Lecturer, Management Department, Faculty of Economic and Business, University of Dian Nuswantoro, Indonesia.

Email: ana.kadarningsih@dsn.dinus.ac.id

${ }^{3}$ Corresponding Author. Lecturer, Accounting Department, Faculty of Economic and Business, University of Dian Nuswantoro, Indonesia [Postal Address: Jl. Nakula I No. 5-11, Semarang, Central Java, 50131, Indonesia] Email: sekretariat@dinus.ac.id; zaky.machmuddah@dsn.dinus.ac.id

${ }^{4} \mathrm{PhD}$ Scholar, Department of Management Sciences, University of Swabi KP-Pakistan, Pakistan. Email: maazyousafzai12@gmail.com

(c) Copyright: The Author(s)

This is an Open Access article distributed under the terms of the Creative Commons Attribution Non-Commercial License (http://Creativecommons.org/licenses/by-nc/4.0/) which permits unrestricted noncommercial use, distribution, and reproduction in any medium, provided the original work is properly cited. the capital adequacy ratio, can be stable above 8 percent, which is 23 percent (Rachman, et. al., 2018). The Law of the Republic of Indonesia Number 10 year 1998 concerning banking describes a bank as a business entity that collects funds from the public in the form of deposits and distributes them to the community in the form of credit or in other forms in order to improve the lives of many people. This places banks as intermediaries between people who have surplus funds and those who lack funds. The function of the bank as an intermediary appears in the bank's efforts to create an interest rate as the risk of the guarantor in the collection and distribution of credit (Santoso, 1995). The amount of credit distribution from banks in Indonesia from 2013 to 2016 can be seen in Figure 1 below:

Figure 1 shows an increase in lending by commercial banks. Increasing credit means making available more of the community's money so that people can borrow money from banks to meet their financial needs (Kholisudin, 2012). Figure 1 illustrates that lending by commercial banks is greater than lending by sharia banks and rural banks. This means that commercial bank products are more diverse and the activities of commercial banks are wider compared to sharia banks and rural banks. 


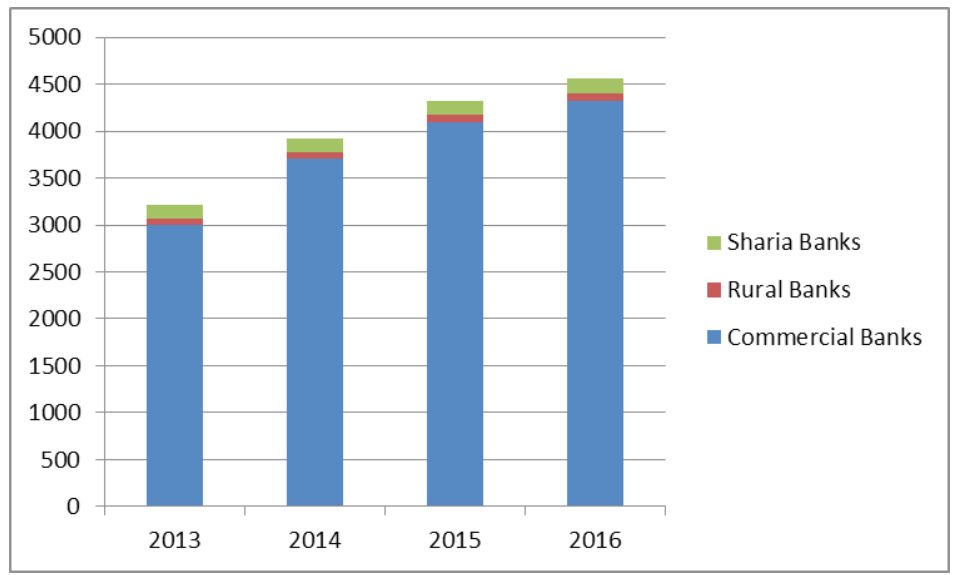

Figure 1: Credit distribution of Commercial Banks, Rural Banks and Sharia Banks in 2013-2016

Source : ojk.co.id

One of the problems faced by banks is inflation. Inflation is related to interest rates; with higher inflation not being offset by an increase in interest rates, investment profits, especially on the money market, can become unattractive, so this can cause a weakening of the exchange rate. In principle, an increase in interest rates can reduce banking enthusiasm in lending to customers. With a banking sector eager to channel credit and with various options offered to customers to meet their needs, banks can provide competitive credit interest. Strong inflationary pressure and rising interest rates also have an impact on bank lending in Indonesia (Haryati, 2009).

According to the Financial Services Authority (OJK), commercial banks' lending increased in the period 2013 to 2017. Lending by commercial banks is greater than that of BPRs and Sharia Commercial Banks, because the activities of commercial banks are wider than those of rural credit banks. This means that commercial banks have the right to determine the types of products and services that will be offered to the public, whereas BPRs have certain restrictions, so that their activities in selling products and operating areas are tighter compared to commercial banks (Kasmir, 2014). Loans disbursed by banks (conventional) constitute the largest portion of assets owned by banks. In a normal financial condition, credit can reach $70 \%$ to $90 \%$ of the bank's assets. Therefore, credit activity is the backbone and the main activity of banks.

There are several factors that affect the distribution of credit, both internal and external (macroeconomic variables). Internal factors related to the bank itself are Capital Adequacy Ratio (CAR), Third Party Funds (DPK) and Return On Assets (ROA), while the macroeconomic variables are the Interest Rate (BI rate) and the economic transition (Firdaus and Ariyanti, 2011). Inconsistent results were also seen in previous studies, namely, the non-positive relationship between economic growth and bank loans caused by the use of all internal funds for bank loans (Takasu \& Nakano, 2019). Based on research by Pratama (2010), Murdiyanto (2012), Yuda and Meiranto (2010) stated that CARs had a negative effect toward lending, while Satria and Subegti (2010) said that CAR had a significant positive effect on lending. This is different from the results found in research conducted by Setyawan (2016), Devi (2016), Pratiwi and Hindasah (2014), and Murdiyanto (2012) who say that CAR is related to lending.

\section{Literature Review}

\subsection{Capital Adequacy Ratio (CAR)}

Capital Adequacy Ratio is a comparison of the bank's own capital with risks arising from financing of total bank assets such as risks due to securities, credit risk, bills with other banks, and investments (Dendawijaya, 2009). In addition, CAR can measure a bank's performance by looking at the ratio between the bank's capital adequacies to cover the risks generated by assets such as the risk of loans extended to customers (Dendawijaya, 2009). CAR is the level of bank capital adequacy in covering risks arising, including credit risk. Each bank must meet the minimum relative amount of capital compared to the value of the bank's assets (Ha, 2019).

CAR also functions as an indicator of the ability of banks to decrease assets because losses caused by assets tend to be risky (Dendawijaya, 2009). Research by Firdaus and Ariyanti (2011) found CAR is a comparison between the amount of capital owned by a bank and risk-weighted assets (ATMR). The greater the credit extended, the greater the ATMR of the bank concerned, so that CAR will decline. Thus, if a bank will 
Dian PRAWITASARI, Ana KADARNINGSIH, Zaky MACHMUDDAH, Maaz UD-DIN /

expand/extend credit, it must pay attention to the amount of capital owned at that time. If CAR is limited or approaching a minimum, then credit expansion must be accompanied by additional capital. If the bank owner does not add capital, the CAR will fall below the applicable provisions of $8 \%$. Another research explains that there is a positive relationship between CAR and loan growth, and suggests an allowance for losses as a moderating variable between CAR and loan growth (Beatty \& Liao, 2011).

\subsection{Third-Party Funds (DPK)}

Third-party funds are funds that come from the community. Funds raised from the community are the largest source of funds owned by banks. These funds can reach $80 \%$ to $90 \%$ of the total funds managed by banks. Funds derived from the public consists of several types demand deposit, deposit, and savings (Dendawijaya, 2009). Demand deposits are third-party deposits at banks whose withdrawals can be made at any time by using checks, giro and other payment orders or by book-entry. In their implementation by banks, demand deposits are administered by banks in an account called checking account.

According to Dendawijaya (2009), deposits or time deposits are third-party funds in banks that can only be withdrawn within a certain period based on the agreement. In contrast to demand deposits, deposit funds will settle at the bank because the depositors (holders) are interested in the interest rates offered by the bank and there is a belief that at maturity the funds can be withdrawn.

Savings accounts are third-party deposits with banks whose withdrawals can only be made according to certain conditions. All banks are allowed to develop various types of savings themselves according to the needs of the community without the need for approval from Bank Indonesia. For example, there are lottery draws, ease of depositing or withdrawing funds (Dendawijaya, 2009).

\subsection{Return On Assets (ROA)}

Return on Assets (ROA) is used by bank management to assess the ability of banks to earn overall profits (Dendawijaya, 2009). Profit is a set of main goal in the business, including in the banking business. If a bank produces a large profit, it generates trust among the public that will benefit the banking sector. Funds received by banks will increase, so the loans extended by banks will also increase. Dendawijaya (2009) explains that the more bank ROA increases, the higher the rate of bank profits achieved from the use of assets. Research by Devi (2016), Yuda and Meiranto (2010), Rangga and Subegti (2010) found that ROA has a positive effect on lending. This result is different from research conducted by Setyawan (2016), Pratiwi and
Hindasah (2014), which state that ROA has no influence on lending. Different research results are shown by Prihartini and Dana (2018), which state that ROA has a negative and significant effect on the distribution of people's business credit.

\subsection{Bank Indonesia Interest Rate}

BI Rate is a monetary policy signal from Bank Indonesia in the form of periodic announcements about interest rates with a one-month tenor. The BI rate is also an effort of Bank Indonesia to achieve the predetermined inflation target and as an indicator of achieving the short-term interest rate desired by Bank Indonesia (Sari, 2013). If there is an increase in interest rates, then the bank must increase deposit rates to increase deposit. The increase in interest on deposits will affect the interest on loans extended so that it will have an impact on the growth of loans (Haryati, 2009). Generally, Bank Indonesia will take action by raising the BI Rate if the forecast of future inflation exceeds the inflation target, but if future inflation is below the inflation target, Bank Indonesia will decrease BI interest rate (Haryati, 2009).

A higher loan amount will increase interest margin, but banks will also face a high risk of non-performing loans from customers (Rachman et. al., 2018). Risks for changes in interest rates have a great effect on a company. According to Mamduh (in Fahmi, 2014), changes in interest rates can cause companies to face two types of risk: 1) the risk of change in income, net income is less than expected; 2) the risk of changes in market value due to changes in interest rates because it is smaller.

\subsection{Economic Growth (EG)}

According to Boediono (2012), economic growth is a process of increasing per-capita output in the long run. Economic growth is associated with an increase in "output per capita". Clearly, there are two sides to it, namely, the total output (GDP) and the total population. Output per capita is total output divided by population. So, the process of increasing output per capita inevitably must be analyzed by looking at what is happening with total output on the one hand, and the population on the other.

Economic growth is a long-term time perspective. An increase in output per capita for one year or two years can then be followed by a decrease in output per capita rather than economic growth. The process of economic growth must be self-generating, which means that the process of growth itself gives birth to the strength for the onset of continued growth in subsequent periods. The use of bank credit for productive financing will support economic growth and increase income. So, it can be said that economic growth is positively influenced by bank credit (Camba \& Camba, 2020). 


\subsection{Financing of Bank (Lending)}

Commercial banks are trying to increase credit growth in terms of both quantity and quality. This is done to improve loan performance and win over the competition, especially to attract customers with a good credit history (Nguyen \& Lien, 2019). The accounting system explains that if economic conditions are good there will be an increase in bank loans, but if the economic conditions are not good there will be a decrease in bank loans (Takasu \& Nakano, 2019).

Definition of lending according to Law No.10 1998 (article 21 paragraph 11): lending is the provision of funds or provision of bills based on lending agreements between banks and other parties that require the borrower to repay the debt after a certain period of time by giving interest. According to Indonesian Banking Accounting Guidelines (PAPI) (2008), lending is the provision of money or bills that can be likened to it, based on a lending agreement among the bank and other party that requires the borrower (debtor) to payback its lending after a certain period of time with the amount of interest, benefits or profit sharing growth; it is a process of increasing per capita output in the long run.

Awalia (2016), in calculating the difference in lending increase (INCR-LN), uses the formula below:

$$
\Delta \text { Bank Credit }=\frac{\text { Credit }_{t}-\text { Credit }_{t-1}}{\text { Credit }_{t-1}} \times 100 \%
$$

\subsection{Hypothesis Development}

CAR is the ratio between the amount of capital owned by a bank and risk-weighted assets (RWA). The greater the credit extended, the greater the bank's ATMR. If a bank will increase lending, it must pay attention to the amount of capital available (Firdaus and Ariyanti, 2011). The high CAR level reflects the stable amount of capital and low risk possessed by the bank, so that it is able to finance operational activities and make a large contribution to profitability. With a large profitability, banks can channel more credit. This indicates that CAR has a positive effect on increasing lending. This statement is supported by research conducted by Satria and Subegti (2010), which state that CAR has a positive effect on lending. The results are also found in research conducted by Setyawan (2016), Devi (2016), Pratiwi and Hindasah (2014), and Murdiyanto (2012) who say that CAR is related to lending. Based on the description above, hypothesis 1 is formulated as follows:

\section{$\boldsymbol{H}_{1}:$ CAR has a positive effect on increasing lending}

According to Setyawan (2016), DPK is a factor that supports bank lending. The greater the DPK, the greater the amount of credit extended. Banks are required to be able to optimally accumulate third party funds. In order to optimally raise third-party funds, banks can provide attractive rewards to the public or can provide maximum service to their customers. This indicates that the DPK has a positive influence on lending. This statement is supported by research conducted by Pratiwi and Hindasah (2014), which state that DPK has a positive effect on lending. Based on the description above, hypothesis 2 is formulated as follows:

\section{$\boldsymbol{H}_{2}: D P K$ has a positive effect on increasing lending}

According to Pratiwi and Hindasah (2014), ROA is a measure to assess the size of the return on the bank's assets. The higher the ROA owned by the bank in terms of asset, the greater the profit or income obtained and the better the bank's position. If the income earned is high, the funds channeled to the community are also high, so that the credit channeled can increase. This indicates that ROA has a positive influence on lending. This statement is supported by research conducted by Devi (2016), which states that ROA has a positive effect on lending. Based on the description above, hypothesis 3 is formulated as follows:

\section{$\boldsymbol{H}_{3}: R O A$ has a positive effect on increasing lending}

The bank company will save the funds and not extend credit to consumers if Bank Indonesia interest rates are too high (Murdiyanto, 2012). Conversely, if the economy improves, Bank Indonesia will tend to raise the BI rate. If the $\mathrm{BI}$ rate rises, the deposit interest rate and loan interest rate will rise. An increase in credit interest rates will cause people to not want to make loans, which will cause credit distribution to decrease (Murdiyanto, 2012). Based on these explanations, it can be concluded that the BI rate has a negative effect on lending. Research conducted by Pratama (2010) also shows that the BI rate has a negative effect on lending. Based on the description above, hypothesis 4 is formulated as follows:

$\boldsymbol{H}_{4}:$ BI rate has a negative effect on increasing commercial bank lending in Indonesia.

Good economic conditions will certainly increase economic growth. With good economic conditions, banks tend to provide loans to the community as working capital. Conversely, if it is felt that the economic condition is deteriorating, banks are reluctant to provide loans to the public because of the unstable financial conditions in the community. This is in line with the opinion of Yustini (2015), which states that if economic growth rises, public income will also increase; patterns of public consumption will tend to increase as well resulting in increased output. Based on 
the description above it can be concluded hypothesis 5 as follows:

$\boldsymbol{H}_{5}:$ Economic Growth (EG) has a positive effect on the increase in commercial bank lending in Indonesia.

\section{Research Methods and Materials}

In this study, the independent variables are Capital Adequacy Ratio (CAR), Third Party Funds (DPK) and Return on Assets (ROA), Interest Rate (BI rate) and Economic Growth and the dependent variable is Financing Bank. The population of this study is Conventional Commercial Banks, which were registered with the Financial Services Authority for the 2014-2017 period.

The sample consisted of 14 banks obeying the following criteria: a) conventional commercial banks registered at OJK in 2014-2017; b) provide complete financial reports from 2014 to 2017; c) a bank whose entire shares are owned by Indonesian citizens; d) banks that continue to experience credit increases from the first quarter of 2014 to the fourth quarter of 2017.

The data collection method uses the literature such as journals, magazines, and other sources, and the documentation approach. The documentation method is by recording data contained in the financial statements of each company. The multiple regression analysis methods were used to determine the influence of the independent variable on the dependent variable. In this analysis, the independent variables influence the dependent variable.

\section{Results and Discussion}

The data analysis technique used in this study is multiple linear regression analysis, which includes descriptive statistics, classic assumption tests, hypothesis testing and regression coefficient tests to describe internal factors and macroeconomic factors that affect the increase in lending of commercial banks in Indonesia. Descriptive statistics are statistics that describe the object under study without conducting analysis and making general conclusions.
Table 1 shows each variable from the minimum value, maximum value, mean value, and standard deviation. The result of descriptive statistics are displayed in Table 1:

Descriptive statistical test results show that the minimum value on the Capital Adequacy Ratio (CAR) is 10.44 and the maximum value is 58.60 , then the mean value is 20.9123 and standard deviation is 6.59260. From the descriptive statistics, the CAR variable shows that the mean value is greater than the standard deviation $(20,9123>6,59260)$, which means that CAR data tend to be stable and there are no data deviations.

Growth Variable Third-Party Funds (DPK) has a minimum value of -64.00 and a maximum value of 53.10, then a mean value of 5.6608 and a standard deviation of 17.08851. From the descriptive statistics, DPK variable shows that the mean value is smaller than the standard deviation $(5.6608<17.08851)$, which means that TPF data tends to be unstable and data deviations occur.

The Return-on-Assets (ROA) variable has a minimum value of 0.08 and a maximum value of 5.57 , then a mean value of 2.6260 and a standard deviation of 1.19417. From the descriptive statistics, the ROA variable shows that the mean value is greater than the standard deviation (2.6260> 1.19417), which means that ROA data tend to be stable and there are no data deviations.

The BI rate variable has a minimum value of 4.75 and a maximum value of 7.67 , then a mean value of 7.0208 and a standard deviation of 0.89091 . From the descriptive statistics, the BI rate variable shows that the mean value is greater than std. deviation (7.0208> 0.89091), which means that the BI rate data tends to be stable and there are no data deviations.

Economic Growth Variable has a minimum value of -2.00 and a maximum value of 4.02 , then a mean value of 1.2242 and a standard deviation of 2.22408. Descriptive statistics of the Petumbuahan Economic variable shows that the mean value is smaller than the standard deviation $(1.2242$ $<2.222408$ ), which means that economic growth data tend to be unstable and data deviations occur.

Variable Increase in Credit Distribution has a minimum value of 0.05 and a maximum value of 38.20 , then a mean

Table 1: Result of Descriptive Statistics

\begin{tabular}{|l|c|c|c|c|c|}
\hline & N & Minimum & Maximum & Mean & Std. Deviation \\
\hline CAR & 168 & 10.44 & 58.60 & 20.9123 & 6.59260 \\
\hline DPK & 168 & -64.00 & 53.10 & 5.6608 & 17.08851 \\
\hline ROA & 168 & .08 & 5.57 & 2.6260 & 1.19417 \\
BI RATE & 168 & 4.75 & 7.67 & 7.0208 & 0.89091 \\
EG & 168 & -2.00 & 4.02 & 1.2242 & 2.22408 \\
INCR-LN & 168 & .05 & 38.20 & 5.8782 & 5.96019 \\
Valid N & 168 & & & & \\
\hline
\end{tabular}


value of 5.8782 and a standard deviation of 5,96019. Descriptive statistics of the variable Increase in Credit Distribution shows that the mean value is smaller than the standard deviation $(5.8782<5.96019)$, which means that data on increasing credit tends to be unstable and data deviations occur.

Multiple linear regression analysis is used to measure the strength of two or more factors, also to explain the relationship between independent factors and dependent factors and their direction (Ghozali, 2016). Based on the research results, the linear regression output is displayed in Table 2:

A constant value of 1,727 indicates that the assumption of the predictor of the independent variable is constant, so the average amount of increase in credit extended is $1,727 \%$. The regression coefficient of the Capital Adequacy Ratio variable value is 0.183 . These results indicate that, if the variable Capital Adequacy Ratio increases by $1 \%$, it causes an increase in lending by $0.183 \%$. The regression coefficient of the variable value of growth of Third Party Funds is 0.075. These results indicate that if the variable growth in ThirdParty Funds increases by $1 \%$, it causes an increase in lending by $0.075 \%$.

The regression coefficient of the variable value of the Return on Assets Ratio is negative 1.443. These results indicate that, if the variable Return on Assets Ratio decreases by $1 \%$, it causes an increase in lending by $1.443 \%$. The regression coefficient of the value of the Bank Indonesia interest rate (BI rate) is 0.439 . These results indicate that, if the $\mathrm{BI}$ rate variable increases by $1 \%$, it causes an increase in Credit Distribution by $0.439 \%$. The regression coefficient of the variable value of Economic Growth is 0.242 . This result shows that, if the variable of Economic Growth increases by $1 \%$, it causes an increase in Credit Distribution by $1,242 \%$.

The results of statistical tests can show that have been Capital Adequacy Ratio (CAR) has a positive and significant effect on increasing the Credit Distribution received. T-test results showed that the variable Capital Adequacy Ratio showed a significance level of 0.001 smaller than 0.05 and the regression coefficient showed a positive direction of 0.183. The growth of Third Party Funds (DPK) has a positive and significant effect on increasing the Credit Distribution received. T test results indicate that the variable Third Party Funds (TPF) shows a significance level of 0,000 less than 0.05 and the regression coefficient shows a positive direction of 0.075. Then, it can be said that Third Party Funds (DPK) have a positive influence on increasing lending.

Return on Assets (ROA) has a positive and significant effect on increasing lending is rejected. T-test results show that the Return on Assets variable shows a significance level of 0,000 less than 0.05 and the regression coefficient indicates a negative direction of 1.443 . Then, it can be said that Return on Assets (ROA) has a negative effect on increasing lending. BI rate has a positive and significant effect on increasing lending is rejected. T test results showed that the BI rate variable showed a significance level of 0.269 greater than 0.05 and the regression coefficient showed a positive direction of 0.439 . Then, it can be said that the interest rate of Bank Indonesia (BI rate) has a positive and not significant effect on increasing lending. Economic Growth has a positive and significant effect on increasing lending, is rejected. The t test results showed that the variable of economic growth showed a significance level of 0.127 greater than 0.05 and the regression coefficient showed a positive direction of 0.242. Thus, it can be said that Economic Growth has a positive and insignificant influence on increasing lending.

\section{Conclusions}

Based on the hypothesis testing the conclusions of this study show that internal factors have a stronger influence to increasing bank lending than external factors. The main variable of internal factors that influences increasing bank lending is Return on Assets (ROA). The Third Party

Table 2: Multiple Linear Regression Analysis Test

\begin{tabular}{|c|c|c|c|c|c|c|}
\hline & \multirow{2}{*}{ Model } & \multicolumn{2}{|c|}{ Unstandardized Coefficients } & \multirow{2}{*}{$\begin{array}{c}\begin{array}{c}\text { Standardized } \\
\text { Coefficients }\end{array} \\
\text { Beta }\end{array}$} & \multirow[t]{2}{*}{$\mathbf{t}$} & \multirow[t]{2}{*}{ Sig. } \\
\hline & & B & Std. Error & & & \\
\hline \multirow{6}{*}{1} & (Constant) & 1.727 & 3.104 & & .556 & .579 \\
\hline & CAR & .183 & .055 & .241 & 3.334 & .001 \\
\hline & DPK & .075 & .021 & .257 & 3.628 & .000 \\
\hline & ROA & -1.443 & .299 & -.348 & -4.833 & .000 \\
\hline & BIRATE & .439 & .396 & .078 & 1.108 & .269 \\
\hline & EG & .242 & .158 & .108 & 1.533 & .127 \\
\hline
\end{tabular}

a. Dependent Variable : Increasing Lending 
Fund (DPK) is the internal factor with the smallest impact increasing bank lending. Based on these conclusions, this study suggests that taking decision on determining the amount of bank lending should take into account more than CAR, DPK growth, ROA, Bank Indonesia Interest Rates, and Economic Growth. These variables can only have a slight effect on increasing lending. Internal factors such as NPL, LDR or non-economic factors also need to be considered in channeling bank credit.

DPK growth has the weakest influence on increasing bank lending, so banks need to develop new strategies and new innovative ways to attract public interest in depositing funds in banks, so banks can increase lending. ROA has the strongest influence on increasing bank lending, so banks are required to reduce NPL if ROA does not experience a continuous decline. Future studies should include noneconomic factors, in addition to internal factors to the company, in increasing lending by banks and other financial institutions such as leasing, sharia banks, rural banks, and another financial companies.

\section{References}

Amelia, K. C., \& Murtiasih, S. (2017). Analysis of the Effect of DPK, LDR, NPL and CAR against the Total Credit Distribution at PT. Bank QNB Indonesia, 2005-2014 Period. Journal of Business Economics, 22(1), 66-74.

Beatty, A., \& Liao, S. (2011). Do Delays in Expected Loss Recognition Affect Banks' Willingness to Lend?. Journal of Accounting and Economics, 52(1), 1-20.

Camba, A. C., \& Camba, A. L. (2020). The Dynamic Relationship of Domestic Credit and Stock Market Liquidity on the Economic Growth of the Philippines. Journal of Asian Finance, Economics and Business, 7(1), 37-46. https://doi.org/10.13106/ jafeb.2020.vol7.no1.37

Dendawijaya, L. (2009). Banking Management second edition. Bogor: Ghalia Indonesia.

Devi, H. P. (2016). Analysis of the Effect of CAMEL and SBI Interest Rates on the Amount of Credit Distribution at Go Public Conventional Commercial Banks in Indonesia 20112014. ProBank, Journal of Economics and Banking, 2(2), 19-27.

Fahmi, I. (2014). Credit Management. Bandung, Indonesia: Alfabeta. [Indonesian]

Firdaus, R., \& Ariyanti, M. (2011). Commercial Bank Credit Management. Bandung: Alfabeta. [Indonesian]

Ghozali, I. (2016). Application of Multivariate Analysis with IBM SPSS 21 Program Edition 7. Semarang, Indonesia: Diponegoro University Publisher Agency. [Indonesian]

Ha, D. V. (2019). The Interactive Relationship between Credit Growth and Operational Self-Sustainability of People's Credit Funds in Mekong Delta Region of Vietnam. Journal of Asian
Finance, Economics and Business, 6(3), 55-65. https://doi. org/10.13106/jafeb.2019.vol6.no3.55

Haryati, S. (2009). Banking Credit Growth in Indonesia: Intermediation and Influence of Macroeconomic Variables. Journal of Finance and Banking, 12(2), 299-310.

Indonesian Institute of Accountants. (2008). Indonesian Banking Accounting Guidelines (PAPI). Bank Indonesia. Edition 2.

Kasmir. (2014). Revised edition of Banking Management. Jakarta, Indonesia: PT Raja Grafindo Persada. [Indonesian]

Kasmir. (2017). Analysis of the tenth edition of the Financial Statements. Jakarta, Indonesia: PT Raja Grafindo Persada. [Indonesian]

Kholisudin, A. (2012). Determinants of Credit Requests at Commercial Banks in Central Java 2006-2010. Economics Development Analysis Journal, 1(1), 10-18.

Law of the President of the Republic of Indonesia. (1998). Banking Law. Article 1. Kemenkeu.go.id.

Murdiyanto, A. (2012). Factors That Influence the Determination of Bank Credit Distribution. Conference in Business Accounting and Management, 1(1), 61-75.

Nguyen, H. H., \& Lien, T. T. (2019). Factors Influencing Family Business Decision for Borrowing Credit from Commercial Banks: Evidence in Tra Vinh Province, Viet Nam. Journal of Asian Finance, Economics and Business, 6(2), 119-122. https:// doi.org/10.13106/jafeb.2019.vol6.no2.119

Normala, S. G. (2013). Factors Affecting Commercial Bank Loans in Indonesia for the Period 2008-2012. Journal of EMBA, 1(3), 931-941.

Pratama, B. A. (2010). Analysis of Factors Affecting Banking Credit Distribution Policy (Study on Commercial Banks in Indonesia, 2005-2009). Journal of Business Strategy, 19(2), 135-148.

Pratiwi, S., \& Hindasah, L. (2014). The Influence of Third Party Funds, Capital Adequacy Ratio, Return On Assets, Net Interest Margin and Non Performing Loans on Commercial Bank Loans in Indonesia. Journal of Management \& Business, 5(2), 192-208.

Prihartini, S., \& Dana, I. M. (2018). The Effect of CAR, NPL, and ROA on the Distribution of People's Business Credit. E-Management Journal Unud, 7(3), 1168-1194.

Rachman, R. A., Kadarusman, Y. B., Anggriono, K., \& Setiadi, R. (2018). Bank-specific Factors Affecting Non-performing Loans in Developing Countries: Case Study of Indonesia. Journal of Asian Finance, Economics and Business, 5(2), 35-42. https:// doi.org/10.13106/jafeb.2018.vol5.no2.35

Santoso, R. T. (1996). Banking Business Loans. Yogyakarta, Indonesia: ANDI. [Indonesian]

Satria, D., \& Subegti, R. B. (2010). Determination of Commercial Bank Loans in Indonesia for the Period 2006-2009. Journal of Finance and Banking, 14(3), 415-424.

Setyawan, O. (2016). The Effect of Dpk, Car, Npl, Roa, Sbi and Economic Growth on Banking Credit Distribution at Commercial Banks Listed on the Indonesia Stock Exchange. KURS, 1(1), 125-139. 
Takasu, Y., \& Nakano, M. (2019). Conservative Loan Loss Allowance and Bank Lending. Journal of Asian Finance, Economics and Business, 6(3), 9-18. https://doi.org/10.13106/ jafeb.2019.vol6.no3.9

Vanovic, M. (2016). Determinants of Credit Growth: The Case of Montenegro. Journal of Central Banking Theory and Practice, 2, 101-118.
Yuda, I. M., \& Meiranto, W. (2010). The Influence of Bank Internal Factors on the Amount of Credit Disbursed (Empirical Study of Banks Listed on the Indonesia Stock Exchange). Journal of Accounting \& Auditing, 7(1), 94-110.

Yustini, T. (2015). The Effect of Interest Rates, Number of Companies and Economic Growth on Working Capital Loans for MSMEs in South Sumatra. Journal of Finance and Banking, 19(3), 463-474. 